\title{
UPAYA MENINGKATKAN KETERAMPILAN MENGAJAR GURU \\ BERBASIS MODEL PEMBELAJARAN TEAM GAME TOURNAMENT MELALUI BIMBINGAN BERKELOMPOK DI SDN 016 BANJAR LOPAK
}

\author{
Bartunus \\ bartunus64@gmail.com \\ SDN 016 Banjar Lopak, Kuantan Singingi, Indonesia
}

\begin{abstract}
This study aims to improve teacher teaching skills based on team game tournament learning models through group guidance. This research was conducted in September - October 2019 at SDN 016 Banjar Lopak with 14 subjects as teachers. The study design uses school action research that has stages of planning, implementation, observation, and reflection. The research instrument used observation sheets. The results showed an increase in teacher teaching skills based on team game tournament learning models in the first cycle by $71 \%$ which is enough to be $87 \%$ which is included in the excellent category. Based on the results and discussion it can be concluded that through group counselling can improve teacher teaching skills based on team game tournament learning models.
\end{abstract}

Keywords: teacher teaching skills, team game tournament, group guidance

\section{ABSTRAK}

Penelitian ini bertujuan untuk meningkatkan keterampilan mengajar guru berbasis model pembelajaran team game tournament melalui bimbingan berkelompok. Penelitian ini dilaksanakan pada bulan September - oktober 2019 di SDN 016 Banjar Lopak dengan subjek sebanyak 14 orang guru. Desain penelitian menggunakan penelitian tindakan sekolah yang memiliki tahapan perencanaan, pelaksanaan, observasi, dan refleksi. Instrumen penelitian menggunakan lembar observasi. Hasil penelitian menunjukkan adanya peningkatan keterampilan mengajar guru berbasis model pembelajaran team game tournament pada siklus I sebesar $71 \%$ yang merupakan kategori cukup menjadi $87 \%$ yang termasuk kategori sangat baik. Berdasarkan hasil dan pembahasan dapat disimpulkan bahwa melalui bimbingan berkelompok dapat meningkatkan keterampilan mengajar guru berbasis model pembelajaran team game tournament.

Kata Kunci: keterampilan mengajar guru, team game tournament, bimbingan berkelompok

\begin{tabular}{|c|c|c|}
\hline Submitted & Accepted & Published \\
\hline 23 Juli 2019 & 04 November 2019 & 14 November 2019 \\
\hline
\end{tabular}

\begin{tabular}{|l|c|c|}
\hline Citation & $:$ & $\begin{array}{c}\text { Bartunus. (2019). Upaya Meningkatkan Keterampilan Mengajar Guru Berbasis Model Pembelajaran Team Game } \\
\text { Tournament Melalui Bimbingan Berkelompok di SDN 016 Banjar Lopak. Jurnal PAJAR (Pendidikan dan } \\
\text { Pengajaran), 3(6), 1313-1321. DOI : http://dx.doi.org/10.33578/pjr.v3i6.7889. }\end{array}$ \\
\hline
\end{tabular}

\section{PENDAHULUAN}

Berdasarkan undang-undang no 20 tahun 2003 pasal 1 ayat 1 dijelaskan bahwa pendidikan merupakan usaha sadar dan terencana untuk mewujudkan suasana dan proses pembelajaran yang bermakna dan menyenangkan agar siswa berperan aktif dalam aktifitas pembelajaran dalam mengembangkan potensi dirinya untuk memiliki kekuatan spiritual keagamaan, pengendalian diri, kepribadian, kecerdasan, akhlak mulia, serta keterampilan yang diperlukan dirinya, masyarakat, bangsa dan Negara.

Pemerintah berupaya meningkatkan potensi dalam dunia pendidikan seperti merevisi kurikulum, meningkatkan anggaran pendidikan, peningkatan kualitas pendidik, pembentukan karakter, sertifikasi pendidik (Nurmala, 2019). Dalam mewujudkan kualitas pendidikan, peranan guru sangat dibutuhkan. Guru mempunyai peranan yang sangat strategis dalam pengembangan proses belajar mengajar di sekolahnya dalam rangka meningkatkan mutu pendidikan. Guru merupakan orang yang memiliki komptensi pengeloaan pendidikan dan bertanggung jawab dalam mengajar, membimbing, mengarahkan, melatih, menilai, dan mengevaluasi peserta didik (Jurianti, 2018). 
Guru harus memahami karakteristik dan kebutuhan siswa dalam pembelajaran, jika guru memahami permasalahan yang dihadapi siswa maka dipercayai bahwa guru dapat memperbaiki kualitas pembelajaran dan prestasi belajar guru melalui kreatifitas dalam mengajar dan kemampuan dalam melakukan evaluasi. Kreatifitas dapat dikembangkan dengan merujuk pada pendekatan maupun model pembelajaran yang terbarukan. Namun fakta di lapangan ditemukan bahwa masih banyak guru yang belum menerapkan pembelajaran yang dapat meningkatkan aktivitas siswa dan prestasi belajarnya. Peneliti menemukan bahwa 1) guru mengajar seadanya, seperti tanpa berpedoman pada buku melainkan sepengetahuan dan seingat guru karena merasa materi yang diajarkan merupakan materi yang selalu ada setiap tahunnya sehingga enggan mengembangkan pada kontekstual siswa; 2) metode mengajar guru yang satu arah dimana guru berperan aktif menyampaikan materi sementara siswa pasif mendengarkan penjelasan guru padahal dalam tuntunan era saat ini adalah siswa diupayakan menemukan solusi dari permasalahan yang

\section{KAJIAN TEORETIS}

\section{Keterampilan Mengajar}

Berdasarkan undang-undang nomor 20 tahun 2003 guru harus memiliki kompetensi dalam proses pembelajaran, dalam menjalankan tugas dan fungsi sebagai pendidik, seorang guru harus memiliki: 1) kemampuan dan keterampilan dasar mengajar seperti membuka pelajaran, menjelaskan, pola variasi, bertanya, memberi penguatan, dan menutup pelajaran; 2) kemampuan dalam mengaplikasikan berbagai pendekatan, strategi, metode dan model pembelajaran seperti pendekatan kontekstual, saintifik, model TGT, NHT, CTL, LC, STAD, dan sebagainya; 3) kemampuan menguasai kelas, seperti memancing siswa dalam bertanya, mampu menjawab dan mengarahkan pertanyaan siswa, mengatur siswa untuk bekerja sama, membimbing siswa melakukan eksperimen, kerja mandiri, dan lainnya; 4) kemampuan mengukur tingkat ketercapaian pembelajaran siswa. Keterampilan guru dalam mengajar sangat diutamakan karena dihadapi berdasarkan apa yang mereka peroleh sendiri dari aktivitas belajarnya; 3) guru kurang memfasilitasi siswa dalam belajar seperti penggunaan media ajar berupa TIK, penggunaan media ajar berupa LKS, maupun menggunakan alat peraga; 4) guru tidak mengelola pembelajaran dengan baik seperti masih banyak siswa yang tidak memperhatikan, dengan berbicara dengan teman atau melakukan aktivitas lain di luar pembelajaran, hal ini karena guru tidak memotivasi siswa dalam belajar padahal banyak metode maupun model pembelajaran yang memfasilitasi aktivitas siswa seperti TGT.

Berdasarkan permasalahan yang ditemukan tersebut maka peneliti berupaya melakukan suatu bimbingan agar guru memiliki kreatifitas untuk membangkitkan motivasi belajar siswa yakni meningkatkan keterampilan mengajar guru berbasis model pembelajaran team game tournament melalui pelaksanaan bimbingan kelompok. Diharapkan melalui upaya ini guru dapat mengembangkan kompetensinya dalam mengajar sehingga dapat memfasilitasi aktivitas belajar siswa yang pada akhirnya menghasilkan prestasi belajar siswa yang baik.

akan membuat proses pembelajaran lebih bermakna dan menyenangkan bagi siswa sekolah dasar, untuk itu kreatifitas guru dalam mengajar harus terus dilatih dan dikembangkan. Keterampilan mengajar merupakan kompetensi professional yang cukup kompleks, sebagai integrasi dari berbagai kompetensi guru secara utuh dan menyeluruh (Mulyasa, 2013).

Menurut Barnawi dan Arifin (2012), "Guru harus menguasai 8 keterampilan mengajar, yaitu 1) keterampilan bertanya, 2) keterampilan memberi penguatan, 3) keterampilan mengadakan variasi, 4) keterampilan menjelaskan, 5) keterampilan membuka dan menutup pelajaran, 6) keterampilan membimbing diskusi kelompok kecil, 7) keterampilan mengelola kelas, 8) keterampilan mengajar perorangan dan kelompok kecil".

Model Pembelajaran Team Game Tournament

Siswa sekolah dasar memiliki karakter suka bermain sehingga menuntut guru untuk 
kreatif dalam meramu pembelajaran menjadi menyenangkan bagi siswa, salah satu model pembelajaran yang tepat adalah model pembelajaran team game tournament yang merupakan salah satu tipe model pembelajaran kooperatif yang menempatkan siswa dalam kelompok-kelompok belajar yang memiliki kemampuan, jenis kelamin, dan suku atau ras yang berbeda (Rusman, 2011). Lebih lanjut model pembelajaran TGT adalah suatu model pembelajaran yang digunakan dalam proses belajar mengajar yang diawali dengan pemberian materi kepada siswa dan menempatkan siswa dalam kelompok-kelompok kecil yang bersifat heterogen dan setiap siswa berperan aktif dalam pembelajaran yang dikemas dalam bentuk turnamen akademik untuk memperoleh skor individu untuk disumbangkan pada skor timnya sendiri. (Saidi, 2019, Ramadhani, 2019).

Langkah-langkah model pembelajaran TGT

Menurut slavin dalam Saidi (2019) langkah-langkah TGT terdiri dari pengajaran, belajar tim, turnamen, dan rekognisi tim.

\section{Pengajaran}

Guru menyampaikan materi di dalam kelas yang mencakup pembukaan, pengembangan, pengarahan praktis tiap komponen dari keseluruhan materi pelajaran. Guru juga menjelaskan teknik dalam model pembelajaran TGT.

\section{Belajar Tim}

Tugas peserta tim adalah menguasai penjelasan guru dan membantu peserta lain untuk memahami materi. Setiap tim mempunyai lembar kegiatan yang digunakan untuk melatih kemampuan selama proses pembelajaran, serta menilai kemampuan sendiri dan teman lainnya. Lembar kegiatan berupa pertanyaan yang sudah disusun guru mengenai materi yang dipelajari.

\section{Game (permainan)}

Game ini disajikan dalam bentuk pertanyaan-pertanyaan yang diperoleh dari presentasi kelas dan kerjasama tim. Setiap peserta bekerjasama satu sama lain dalam menyelesaikan pertanyaan.

\section{Turnamen}

Guru terlebih dahulu menyediakan lembar permainan, lembar pertanyaan, lembar skor, dan satu boks kartu bernomor untuk setiap meja permainan.

Sebelum turnamen dimulai, siswa yang memiliki kemampuan setara duduk atau dikelompokkan menjadi satu meja turnamen. Berikut gambar susunan meja turnamen

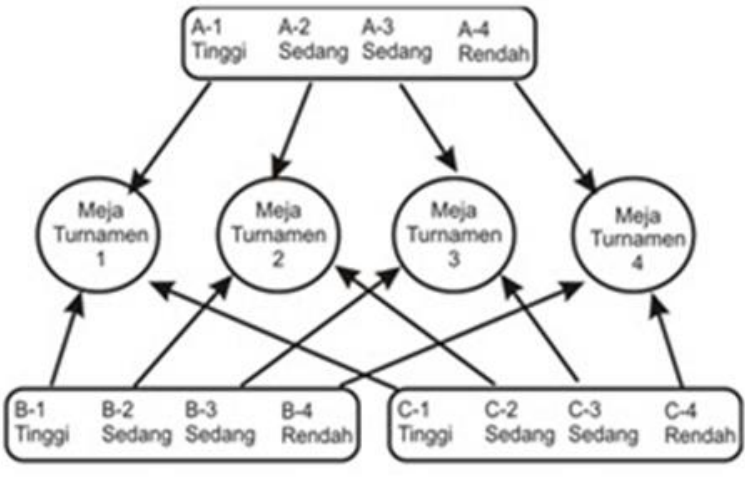

Gambar 1. Penempatan Meja Turnamen

Untuk memulai turnamen, para siswa dalam setiap meja turnamen menarik kartu bernomor untuk menentukan pembaca yang pertama, yakni siswa yang mendapat nomor tertinggi. Pembaca mengocok kartu bernomor dan mengambil kartu yang paling atas, kemudian membaca dan menjawab pertanyaan sesuai dengan nomor pada kartu yang diambil. Setelah pembaca memberikan jawaban, penantang I mempunyai pilihan untuk menantang dan memberikan jawaban yang berbeda atau melewatinya. Begitu pula dengan penantang II, 
jika ia mempunyai jawaban yang berbeda dengan pembaca dan penantang I, maka penantang II atau penantang terakhir boleh menantang atau memilih untuk melewatinya.

Setelah semua peserta memberikan jawaban atau melewati pertanyaan, penantang terakhir memeriksa dan membacakan jawaban yang benar. Siswa yang memberikan jawaban dengan benar akan menyimpan kartunya. Jika jawaban yang diberikan pembaca salah, maka pembaca tidak mendapatkan sanksi. Namun, jika jawaban yang diberikan penantang salah, maka penantang mendapatkan sanksi, yaitu harus mengembalikan kartu kemenangannya. Untuk putaran berikutnya, semua peserta bergerak satu posisi, yaitu penantang I menjadi pembaca, penantang II menjadi penantang I, dan pembaca menjadi penantang II. Setelah turnamen selesai, siswa mencatat nomor yang telah dimenangkan pada lembar skor permainan dan menambahkan poin yang diperoleh pada setiap game.

\section{Rekognisi Tim}

Setelah diperoleh hasil, kemudian dihitung skor peningkatan individu berdasarkan selisih perolehan skor kuis terdahulu (skor dasar) dengan skor kuis terakhir.

\section{Bimbingan Berkelompok}

Guru dalam melaksanakan tugas dan fungsinya harus memiliki kompetensi yang baik

\section{METODE PENELITIAN}

Penelitian ini dilakukan terhadap 14 orang guru yang terdiri dari 5 guru laki-laki dan 9 guru perempuan, dari 14 orang guru tersebut dikelompokkan 3 kelompok yang dipilih berdasarkan kelas dan mata pelajaran yang diampu yakni 1 kelompok berisikan guru kelas 13, 1 kelompok berisi kelas 4-6, dan 1 kelompok lagi berisikan guru bidang studi (agama, olahraga, seni budaya \& muatan lokal, dan penjaskes). Penelitian dilaksanakan mulai 9 September hingga 24 Oktober 2019. Tempat penelitian ini adalah SDN 016 Banjar Lopak Kec. Benai yang merupakan tempat peneliti bertugas.

Desain penelitian yang digunakan adalah penelitian tindakan sekolah yang memiliki sehingga kualitas pembelajaran dan prestasi belajar siswa menjadi meningkat. Untuk itu guru harus melatih dan mengembangkan kompetensinya dengan melaksanakan supervisi yang dilakukan oleh kepala sekolah atau pengawas. Salah satu supervisi adalah bimbingan berkelompok yang merupakan suatu pembinaan terhadap sejumlah guru yang memiliki kualifikasi yang sama, oleh satu atau beberapa supervisor yang memiliki spesialisasi yang berbeda. Materi yang disampaikan supervisor dibahas bersama guru-guru dan disimpulkan bersama (Pidarta, 2009). Lebih lanjut bimbingan berkelompok menurut Ernalis (2019) merupakan pembinaan yang dilakukan terhadap sejumlah guru yang memiliki kualifikasi yang sama yang memiliki masalah dan kebutuhan yang sama serta diberikan layanan supervisi secara bersama.

Teknik bimbingan kelompok menurut Gwynn (dalam Ernalis, 2019) antara lain: (1) Kepanitiaan, (2) kerja kelompok, (3) laboratorium dan kurikulum, (4) membaca terpimpin, (5) demontrasi pembelajaran, (6) darmawisata, (7) kuliah/studi, (8) diskusi panel, (9) perpustakaan, (10) organisasi profesional, (11) buletin supervisi, (12) pertemuan guru, (13) lokakarya. Menurut Pidarta, teknik supervisi kelompok ada beberapa jenis, yaitu (1) rapat guru, (2) supervisi sebaya, (3) diskusi, (4) demontrasi, (5) pertemuan ilmiah, (6) kunjungan ke sekolah lain.

tahapan perencanaan (planning), pelaksanaan (action), observasi (observation), dan refleksi (reflection) yang disebut dengan siklus. Tindakan yang direncanakan dan dilaksanakan pada guru adalah bimbingan berkelompok untuk meningkatkan keterampilan mengajar guru berbasis model pembelajaran team game tournament.

Analisis Data

Instrumen penelitian yang digunakan adalah lembar observasi yang mengamati dan menilai tindakan guru dalam menerapkan model pembelajaran TGT, hasil observasi dinilai dan dihitung menggunakan rumus: 
Nilai akhir $=\frac{\text { skor perolehan }}{\text { skor maksimal }} \times 100 \%$

(Rifdan, 2018)
Nilai akhir yang diperoleh guru dalam menerapkan model pembelajaran TGT dideskripsikan ke dalam kategori pencapaian hasil penelitian yang diadopsi dari Asmina (2018) berikut:

Tabel 1. Kategori Pencapaian Hasil Penelitian

\begin{tabular}{cc}
\hline Nilai Akhir (\%) & Kategori \\
\hline $85-100$ & Sangat Baik \\
$75-84$ & Baik \\
$60-74$ & Cukup \\
$50-59$ & Kurang \\
$\leq 49$ & Sangat Kurang \\
\hline
\end{tabular}

Indikator keberhasilan penelitian ini adalah 1) seluruh guru mencantumkan model pembelajaran team game tournament dalam perencanaan pembelajaran yang dibuat; 2) guru

\section{HASIL DAN PEMBAHASAN}

\section{Siklus I}

\section{Perencanaan}

Sebelum penelitian dilakukan, peneliti mengadakan pertemuan dengan para guru untuk melaksanakan penelitian tindakan sekolah. Penelitian dimulai dengan menyampaikan tujuan dan proses penelitian yang dilakukan. Peneliti meminta guru menyiapkan perencanaan pembelajaran yang menerapkan model pembelajaran team game tournament. Perihal model pembelajaran guru diberikan penjelasan terlebih dahulu agar guru tidak kebingungan dalam membuat perencanaan pembelajaran berbasis TGT. Setelah peneliti dan guru menemui kesepahaman maka peneliti menyiapkan lembar observasi pelaksanaan yang mengacu pada perencanaan yang telah disepakati di awal.

\section{Pelaksanaan}

Pelaksanaan dilakukan dengan kelompok yang telah dibagi sebelumnya. Setiap kelompok melakukan kegiatan pembelajaran yang dilakukan oleh 1 orang guru dari masing-masing kelompok dan guru lainnya sebagai observer menerapkan model pembelajaran team game tournament dalam proses pembelajaran sebagai bentuk keterampilan dalam mengajar di kelas dengan pencapaian pada kategori sangat baik.

yang membantu peneliti melakukan pegamatan dan penilaian terhadap penerapan model pembelajaran TGT di kelas. Masing-masing guru berperan untuk memperbaiki proses pembelajaran agar siswa berperan aktif dalam pembelajaran melalui arahan dari guru.

\section{Observasi}

Selama proses pembelajaran berlangsung, 1 orang guru menerapkan model pembelajaran TGT dan lainnya membantu peneliti melakukan pengamatan dan penilaian. Adapun hasil observasi keterampilan mengajar guru menggunakan model pembelajaran TGT yang diamati oleh masing-masing observer dapat dilihat pada tabel berikut: 
Tabel 2. Keterampilan Mengajar Guru Berbasis Model Pembelajaran Team Game Tournament Siklus I

\begin{tabular}{cccccc}
\hline \multirow{2}{*}{ Keterampilan Mengajar TGT } & \multicolumn{3}{c}{ Kelompok guru } & \multirow{2}{*}{$\begin{array}{c}\text { Rata-rata } \\
\text { klasikal (\%) }\end{array}$} & \multirow{2}{*}{ Kategori } \\
\cline { 2 - 4 } & I & II & III & 80 & Baik \\
1) & 4 & 4 & 4 & 60 & Cukup \\
$3)$ & 3 & 3 & 3 & 66 & Cukup \\
$4)$ & 3 & 3 & 4 & & Baik \\
$5)$ & 4 & 4 & 4 & 80 & Sangat Baik \\
6 () & 4 & 5 & 4 & 86 & Cukup \\
$7)$ & 3 & 3 & 3 & 60 & Cukup \\
$8)$ & 4 & 3 & 3 & 66 & Cukup \\
& & 4 & 3 & 73 & Cukup \\
\hline
\end{tabular}

Keterangan:

1) keterampilan bertanya, 2) keterampilan memberi penguatan, 3) keterampilan mengadakan variasi, 4) keterampilan menjelaskan, 5) keterampilan membuka dan menutup pelajaran, 6) keterampilan membimbing diskusi kelompok kecil, 7) keterampilan mengelola kelas, 8) keterampilan mengajar perorangan dan kelompok kecil.

Hasil observasi pada tabel 2 menunjukkan bahwa rata-rata keterampilan mengajar guru berbasis model pembelajaran TGT memperoleh rata-rata sebesar $71 \%$ yang merupakan kategori cukup. Dapat dikatakan hasil ini belum sesuai dengan harapan peneliti. Hasil ini terjadi karena 1) guru belum maksimal dalam memberikan penguatan atas permasalahan atau pertanyaan yang terjadi dalam pembelajaran sehingga siswa masih belum seluruhnya memahami apa yang ditanyakan dalam pembelajaran.

Menurut Mudlofir (2012) Penguatan adalah respons terhadap suatu tingkah laku yang dapat meningkatkan kemungkinan berulangnya kembali tingkah laku tersebut; 2) guru kurang melakukan variasi dalam proses pembelajaran sehingga pelaksanaan terlihat kaku; 3) dalam membimbing diskusi siswa bersama kelompoknya, guru terlihat kesulitan karena siswa banyak yang diam dan malu untuk mengemukakan pendapat; 4) keterampilan guru dalam mengelola kelas masih belum baik terlihat dari banyaknya siswa yang tidak fokus pada pelajaran dan beberapa siswa sibuk dengan aktifitas di luar pembelajaran seperti menggambar maupun berbicara dengan teman sebangku; 5) dalam hal keterampilan mengajar guru masih belum terbiasa mengajar perorangan ataupun kelompok kecil, terlihat dari banyaknya siswa yang kurang berpartisipasi dalam kelompoknya. Beberapa keterampilan yang menonjol adalah 1) keterampilan bertanya dimana guru sudah memancing pembelajaran dengan pertanyaan pembuka dan pengarah, guru juga menunjuk siswa untuk menjawab pertanyaan yang diajukan sehingga semua siswa harus siap jika diberikan pertanyaan oleh guru; 2) keterampilan menjelaskan juga terlihat baik, hal ini merupakan cerminan kebiasaan mengajar guru yang senantiasa memberikan penjelasan dalam mengajar di kelas; dan 3) guru sangat terampila dalam membuka dan menutup pelajaran terlihat saat membuka pelajaran guru mengajak siswa untuk bersemangat dan memberikan pertanyaan pembuka dengan terlebih dahulu melakukan demonstrasi sederhana, pada penutupan pelajaran guru memberikan apresiasi bagi kelompok yang menang.

\section{Refleksi}

Mengamati hasil dan pembahasan di atas, keterampilan mengajar guru berbasis model pembelajaran TGT masih belum memenuhi kriteria keberhasilan yang diharapkan sehingga perlu perbaikan pada siklus selanjutnya yang mengacu pada kekurangan yang terjadi pada siklus I yakni pada keterampilan memberikan penguatan, mengadakan variasi, membimbing diskusi kelompok kecil, mengelola kelas, dan mengajar perorangan dan kelompok kecil. Masukan berdasarkan hasil observasi dan diskusi dengan observer adalah guru harus menyiapkan variasi pembelajaran dalam pelaksanaan pembelajaran di kelas, menyiapkan pertanyaan 
dan informasi untuk penguatan, serta manajemen waktu dan kelas dengan memberikan tanggung jawab pada ketua masing-masing kelompok siswa.

\section{Siklus II}

\section{Perencanaan}

Perencanaan pada siklus II sama dengan siklus I, perbedaan hanya terletak pada pemaksimalan keterampilan yang memperoleh nilai yang cukup. Perbaikan mengacu pada refleksi yang dikemukakan pada siklus I dimana guru harus menyiapkan variasi pembelajaran, pertanyaan dan penguatan materi, serta manajemen kelas dengan memberikan tanggung jawab pada masing-masing kelompok.

\section{Pelaksanaan}

Guru melaksanakan pembelajaran sesuai dengan perencanaan pembelajaran yang telah disusun berdasarkan perbaikan siklus I. Dalam pelaksanaan pembelajaran guru tampak lebih percaya diri dan mampu mengatur kelas dengan baik, aktivitas siswa terlihat lebih banyak yang berpartisipasi dalam pembelajaran.

\section{Observasi}

Berdasarkan hasil pengamatan yang dilakukan oleh observer terhadap pelaksanaan pembelajaran yang dilakukan guru pada siklus II tampak ada peningkatan yang lebih baik. Hasil observasi keterampilan mengajar guru berbasis model pembelajaran team game tournament pada siklus II dapat dilihat pada tabel berikut:

Tabel 3. Keterampilan Mengajar Guru Berbasis Model Pembelajaran Team Game Tournament Siklus II

\begin{tabular}{ccccccc}
\hline \multirow{2}{*}{ Keterampilan Mengajar TGT } & \multicolumn{3}{c}{ Kelompok guru } & \multicolumn{2}{c}{$\begin{array}{c}\text { Rata-rata } \\
\text { klasikal (\%) }\end{array}$} & Kategori \\
\cline { 2 - 4 } & I & II & III & 86 & Sangat Baik \\
1) & 4 & 5 & 4 & 80 & Baik \\
3) & 4 & 5 & 3 & 86 & Sangat Baik \\
$4)$ & 4 & 4 & 5 & 93 & Sangat Baik \\
$5)$ & 5 & 5 & 4 & 93 & Sangat Baik \\
$6)$ & 4 & 5 & 5 & 80 & Baik \\
$7)$ & 4 & 4 & 4 & 86 & Sangat Baik \\
$8)$ & 5 & 4 & 4 & 93 & Sangat Baik \\
& 5 & 5 & 4 & & $\mathbf{8 7}$ & Sangat Baik \\
\hline
\end{tabular}

Berdasarkan tabel 3 dapat dilihat bahwa rata-rata keterampilan mengajar guru berbasis model pembelajaran team game tournament adalah sebesar $87 \%$, hal ini menunjukkan bahwa keterampilan mengajar guru sangat baik dalam menggunakan pembelajaran berbasis TGT. 1) Kemampuan bertanya guru semakin baik terlihat dari pertanyaan yang diajukan seputar pengetahuan siswa berkaitan dengan lingkungan siswa dengan metode pertanyaan yang lebih menantang; 2) keterampilan memberikan penguatan lebih jelas karena guru memberikan gambaran baik menggunakan tampilan di papan tulis maupun menggunakan alat pembelajaran; 3) guru lebih bervariasi dalam mengajar sehingga pembelajaran menjadi menyenangkan dan bermakna bagi siswa; 4) guru semakin terampil dalam memberikan penjelasan dengan terlebih dahulu mengambil jawaban-jawaban yang dikemukakan oleh siswa; 5) keterampilan membuka dan menutup lebih variatif karena guru melibatkan siswa dalam demonstrasi di awal dan mereview pendapat siswa untuk menutup pelajaran; 6) guru lebih terampil dalam membimbing diskusi siswa, hal ini sangat bermanfaat bagi siswa dalam mengembangkan kemampuan berpikir dan berkomunikasi, meningkatkan disiplin, meningkatkan motivasi belajar, mengembangkan sikap saling membantu, dan meningkatkan pemahaman yang mereka peroleh dari model TGT (Barnawi, 2012); 7) pengelolaan kelas lebih baik karena siswa lebih tenang dan berpartisipasi aktif untuk memperoleh manfaat dalam proses pembelajaran, dalam hal ini berusaha memperoleh skor yang tinggi untuk tim dan memahami setiap penjelasan yang 
disampaikan; 8) guru tampak lebih siap dalam mengajar kelompok kecil karena guru mampu menjalin kedekatan emosional dengan siswa, siswa merasa butuh untuk bertanya pada guru dan guru merasa senang dalam memberikan penjelasan terdahap pertanyaan siswa.

\section{Refleksi}

Melihat hasil dan pembahasan di atas, hal ini mencerminkan adanya peningkatan yang signifikan pada keterampilan mengajar guru berbasis model pembelajaran team game

\section{SIMPULAN DAN REKOMENDASI}

Penelitian yang dilakukan tehadap guru SD menghasilkan keterampilan mengajar guru berbasis model pembelajaran team game tournament melalui bimbingan berkelompok pada siklus I sebesar $71 \%$ dengan kategori cukup meningkat menjadi $87 \%$ yang termasuk dalam kategori sangat baik. Berdasarkan hasil penelitian dan pembahasan tersebut dapat disimpulkan bahwa melalui bimbingan berkelompok dapat meningkatkan keterampilan mengajar guru berbasis model pembelajaran team game tournament.

\section{DAFTAR PUSTAKA}

Barnawi dan Arifin, M. (2012). Etika dan Profesi Kependidikan. Jogjakarta: Ar-Ruzz Media.

Emda, A. (2016). Strategi Peningkatan Kinerja Guru Yang Profesional. Lantanida Journal, 4 (2), 111-117.

Ernalis. (2019). Upaya Meningkatkan Keterampilan Mengajar Guru Matematika SD dalam Merancang Pembelajaran Berbantuan Alat Peraga melalui Bimbingan Berkelompok. Jurnal PAJAR (Pendidikan dan Pengajaran), 3 (4), 847-858.

Juliana, S. (2019). Implementasi Supervisi oleh Pengawas Sekolah Terhadap Peningkatan Keterampilan Guru dalam Proses Belajar Mengajar. Jurnal PAJAR (Pendidikan dan Pengajaran), 3 (4), 744-750.

Jurianti. (2018). Peningkatan Keterampilan Mengajar Guru pada Mata Pelajaran IPS Melalui Supervisi Akademik SD Negeri 038 Pulau Kijang. Jurnal PAJAR tournament bahwa guru memperoleh rata-rata sebesar $87 \%$ yang termasuk kategori sangat baik. Merujuk pada indikator keberhasilan yang diharapkan maka penelitian ini dianggap berhasil dan tidak perlu dilanjutkan pada siklus berikutnya. Hasil penelitian ini juga senada dengan Ernalis (2019) bahwa keterampilan mengajar guru mengalami peningkatan melalui bimbingan berkelompok. Peran kepala sekolah memiliki pengaruh terhadap keterampilan mengajar guru (Juliana, 2019).

Rekomendasi yang dapat diberikan adalah agar peneliti berikutnya lebih memandang karakteristik siswa sehingga peneliti dapat menentukan solusi terhadap permasalahan yang dihadapi siswa melalui peningkatan kompetensi guru, peneliti bisa memperbaiki perencanaan, pelaksanaan, maupun evaluasi pembelajaran dengan memasukkan model pembelajaran inovatif maupun evaluasi pembelajaran yang terbaru dan dapat meningkatkan kemampuan dan prestasi siswa

(Pendidikan dan Pengajaran), 2 (6), 928935.

Mudlofir, A. (2012). Pendidik Profesional (Strategi dan Aplikasinya dalam Pendekatan Mutu Pendidikan di Indonesia). Jakarta: PT Raja Grafindo Persada.

Mulyasa, E. (2013). Menjadi Guru Profesional Menciptakan Pembelajaran Kreatif dan Menyenangkan. Bandung: PT Remaja Rosdakarya.

Nurmala., Murniati, A.R., \& Bahrun. (2019). Efektivitas Pelaksanaan Supervisi oleh Pengawas dalam Meningkatkan Kompetensi Profesional Guruipa pada SMP Negeri 3 Ingin Jaya Kabupaten Aceh Besar. Jurnal Magister Administrasi Pendidikan, 7 (1), 26-34.

Pidarta, M. (2009). Supervisi Pendidikan Kontekstual. Jakarta: Rineka Cipta. 
Ramadhani, U. (2019). Meningkatkan Kemampuan Memahami Bacaan dengan Model Pembelajaran Kooperatif Tipe Teams Game Turnament (TGT) pada Siswa Kelas IV SDN 010 Langgini. Jurnal PAJAR (Pendidikan dan Pengajaran), 3 (5), 1153-1161.

Rifdan. (2018). Upaya Meningkatkan Kemampuan Guru dalam Penggunaan Media TIK melalui Kegiatan Workshop di SMPN 2 Teluk Kuantankecamatan Kuantan Tengah Kabupaten Kuantan Singingi. Jurnal PAJAR (Pendidikan dan Pengajaran), 2 (5), 827-835.

Rusman. (2011). Model-Model Pembelajaran Mengembangkan Profesionalisme Guru. Jakarta: PT. Rajagrafindo Persada.

Saidi. (2019). Peningkatan Motivasi dan Hasil Belajar Pecahan dengan Menggunakan Pendekatan Kooperatif Tipe TGT di Kelas V SDN 04 Kayu Manang. Jurnal PAJAR (Pendidikan dan Pengajaran), 3 (5), 10521064. 